\title{
MSTN Gene
}

National Cancer Institute

\section{Source}

National Cancer Institute. MSTN Gene. NCI Thesaurus. Code C24425.

This gene plays a role in cell differentiation and the regulation of transcription. It is also involved in the regulation of muscle mass. 